\title{
A Review of Designing Ventilators Using Different Mechanisms
}

\author{
Monika Bhole ${ }^{1}$, Kritika Jain ${ }^{2}$, Advait Kolse ${ }^{3}$, Pallavi Gadewar ${ }^{4}$ and B.M. Hardas ${ }^{5}$ \\ ${ }^{1}$ Department of Electronics Engineering, Shri Ramdeobaba College of \\ Engineering and Management, Nagpur, Maharashtra, India
}

\section{ABSTRACT}

A ventilator is the key medical equipment required during an accident or any disease. It is required when human life is in danger, and the patient feels difficulty in breathing, external support is provided from outside by a machine. With the increase in new lung diseases, it has now been important to build a Ventilator, which will be as effective as available in the clinic and can be provided in large numbers by considering different situations. Since the ventilators available in medical centers are bulky and costly, and the shortage of such critical equipment can lead to threatening human life. In this study, the academic literature reviews various Ventilator Mechanisms and ventilation techniques, mostly considering the positive pressure ventilation and high-frequency ventilation and different parameters to consider. There is a large amount of future work needed to move open source ventilators up to the level considered scientific-grade equipment, and even further work needed to reach medical-grade hardware so that the patients can get proper treatments. With the ongoing pandemic, it is assumed these projects will gather greater attention and resources to make significant progress and have reached a functional system. The paper describes a systematic literature review of peer-performed projects and reviews journal articles published in recent ventilator designs.

\section{KEY WORDS: VENTILATOR, PANDEMIC, DESIGNING, AMBU-BAG, HIGH FREQUENCY, CONTROLLER.}

\section{INTRODUCTION}

In developed and industrialized countries, Chronic respiratory diseases or respiratory failure is a major public health challenge. Respiratory diseases like Acute respiratory infections, Chronic bronchitis, Asthma, and others are very widely spread all over the globe. These diseases are increasing very rapidly and are having an economic impact. Various critical technologies are generally available in the medical field, but they are not available in a large amount.

\section{ARTICLE INFORMATION}

*Corresponding Author: bholemv@rknec.edu

Received 17th Oct 2020 Accepted after revision 30th Dec 2020

Print ISSN: 0974-6455 Online ISSN: 2321-4007 CODEN: BBRCBA

Thomson Reuters ISI Web of Science Clarivate Analytics USA and Crossref Indexed Journal

\section{Clarivate
Analytics}

NAAS Journal Score 2020 (4.31)

A Society of Science and Nature Publication,

Bhopal India 2020. All rights reserved.

Online Contents Available at: http//www.bbrc.in/

Doi: http://dx.doi.org/10.21786/bbrc/13.14/112
There are various ventilators mentioned by researchers. They have been differentiated based on their ventilation supports which can be categorized based on high frequency jet ventilation, positive pressure ventilation and negative pressure ventilation, the mechanism used for breathing i.e. mechanical or electronic or electromechanical, and parameters that control them. During pandemic like COVID-19, specialists are facing a shortage of medical supplies. Hence, people are dying because of COVID-19 and the lack of these supplies. The shortage of one of these medical supplies which is most important during this pandemic is low-cost and portable ventilators. Hence, there is a critical need for designing the ventilator that is low in cost, portable and easy to use anywhere with and without any higher medical authorities.

Design And Ventilation Techniques: The first ventilator is a machine-controlled respiration process. They divided the device into three parts- electronic, pneumatic, and mechanical. The electronic system consists of interfacing and sensing components, whereas the pneumatic system 
has components that control the airflow. The authors used 2 actuators in the pneumatic system to control the Peak Inspiratory Pressure (PIP) and Positive End Expiratory Pressure (PEEP). These are used because if the pressure in the lungs is more or less than the standard values, it may lead to lung damage.

The right pressure of air to the lungs can be set using the tidal volume and IE(inspiratory to respiratory) ratio which are continuously displayed on the LCD screen inserted in the device. The researchers used arm cortex architecture as their microcontroller and Keil Uvision for cross-compiling. This whole system runs in closed-loop control, which is constantly rectified by a PID controller algorithm. By constant feedback, the machine adjusts itself to the I:E ratio the patient demands, to avoid any damage to his lungs. This prototype was simulated and the results founded with regards to the pressure maintaining parameters showed little deviations.

Other researchers used an AMBU bag for ventilation. It is mostly used because of its auto relaxation property. The authors used 2 servo motors and 2 cam arms. The 2 cam arms placed in "V" shape are pulled towards each other by cross connection of servo motors, causing the AMBU bag to squeeze. An Arduino along with buttons is used to select from 3 modes-child, pediatric, and adult. By adjusting the I:E ratio, tidal volume and respiratory rate we can make a single device work for different ages. The amount of air squeezed out from the bag is decided by the angle created between the "V" shape which holds the Ambu bag. This amount of air is measured by a flow meter. A similar design was used by a Pakistan university, but instead of 2 servo motors and 2 cam arms, they used a single geared motor along with a rack and pinion mechanism for squeezing the bag. They used Thermistor for the detection of breathing. Both the researchers claimed that it is an energy efficient, portable and affordable ventilator.

Another type of ventilator proposed by Taiwan University is the high-frequency jet ventilator. This is a pressurecontrolled ventilator. The high-frequency jet ventilator is generally preferred over conventional ventilators because of its smaller tidal volume. Mostly, conventional ventilators cause barotrauma, i.e. excessive air enters the lung and damages the alveoli. Another reason for its selection is, it uses a thinner tube that replaces the endotracheal tubes, which constantly injects small volumes of gas through it. This system is divided into 2 parts: the main unit and the feedback unit. The main unit consists of flow control valves, flow meters, check valves, a gas chamber, a solenoid. valve. Whereas, the feedback unit uses flow control valves, a gas chamber, a pressure sensor, and control circuits.

The flow control valve and flow meter are used to regulate and check the amount of air/oxygen that has been delivered to it. After altering it to the required rate, this mixed gas goes into a gas chamber to blend. Later, this blended gas is delivered to the output of the ventilator through a solenoid valve. Whenever, there are problems like instability of airflow, an insufficient supply of oxygen, or standard I:E ratio is not maintained, then the feedback control comes into action. A programmed microcontroller checks the value that is set by the clinician with the measured value that is brought back into the system, if they are found to be unequal it alters the setting of the flow control valve to achieve the desired value. This system also has an LCD for display and buttons for alteration purposes. It was tested on an animal and it proved to be effective.

Scientists of Dr. APJ Abdul Kalam Missile Complex, RCI, DRD0-Hyderabad designed a ventilator named "DEVEN". This ventilator design has microcontroller operated solenoid valve and very precisely measure important parameters like inspiratory pressure, respiration (breathe) rate, I:E ratio, tidal volume, and percentage oxygen (Fi02). This design is developed by using HRCS(hot gas reaction control system). HRCS is achieved by actuating solenoid valves through a microcontroller to control the flow of oxidizer as well as fuel. Solenoid valves are controlled for Inspiratory and expiratory lines by existing controllers. All the parameters of the ventilator are controlled using manual valves/touch screen and are displayed using serial communication link onto a touch-screen LED display. The doctor/hospital attendants can vary these parameters depending upon the patient's breathing requirement. Different categories of patients have different respiration rates and hence require different inhalation and exhalation of air as well as oxygen.

All the parameters (except FiO2) are controlled on the touch screen which in turn controls the opening and closing times of the solenoid valves. FiO2 is controlled manually by suitably positioning the knob of a three-way valve. Air and oxygen enter through this valve at two inlets and a mixture of both air and oxygen comes out from the outlet of this valve and this mixture of both gases is subjected to the patient through the inspiratory solenoid valve. DEVEN ventilator system has two modes of operation:(a) Hospital mode. (b) Stand-alone mode. In hospital mode, DEVEN draws compressed air and oxygen, both available at 5 bar pressure from centralized hospital compressed air and oxygen supply lines. In standalone mode, compressed air at 5 bar pressure is supplied from compressor and air reservoir, and oxygen is supplied from an oxygen cylinder, through a pressure regulator. This pressure regulator reduces the pressure of oxygen (from cylinder) to 5 bar.

Authors also tried to bring precision in breathing using analog sensors. The researchers demonstrated the use of these analog sensors in a closed loop, in both volumes controlled and pressure-controlled techniques. Here DC air pump was used along with a buck converter and 2 MOSFETS to control its speed. The analog flow rate sensor and analog pressure sensor were input to a comparator along with a sawtooth signal generator. The output of the comparator was a PWM signal. The amount of air traveling through the flow rate sensor was calculated by an equation. The pressure was also 
calculated by using an equation that was then modelled by a transfer function. These equations were obtained by using CFTOOL (X, Y) in MATLAB.

In the volume-controlled technique, the flow rate sensor was used as a feedback path, whereas for pressurecontrolled technique, pressure sensor was as the feedback path. The preset data would come from Raspberry Pi which the researchers used as an interfacing platform and this data would be compared with the data from the sensors in a microcontroller. Later the difference between them served as an input to the PID controller which would correct the values and prevent the lungs from any injury. The noise was created due to the variable duty PWM, so to remove this the authors used a Low pass filter on it. The research team proved their accuracy by providing graphical results of the device.

Researchers also prepared a device that prevents Ventilator-associated Pneumonia (VAP), a nosocomial disease, which happens due to the use of endotracheal intubation during mechanical ventilation. It is an AIdriven-cost effective device. The device, named VAPCare, basically senses the secretion and performs a mouthwash to prevent bacteria from entering the lungs. It is divided into 2 parts- the main unit and the sensing unit. The main unit is where all interfacing takes place, which consists of a screen, keypad, and knobs. The sensing unit senses the secretion or bacteria and sucks it into a container.

The suction is performed by applying negative pressure and can be adjusted accordingly for each patient. It has a range from $45 \mathrm{mmHg}$ to $120 \mathrm{mmHg}$. Later, a container with medicated disinfectant, i.e. lavage, is sprayed at that region concurrently sucking back the extra lavage. This sensing and spraying of lavage have a default frequency which it takes place (30 min and 50 min correspondingly), but can be altered by using the frequency buttons. This prototype wasn't performed on any human. The authors ran benchtop testing with 3-6 months of constant use. They provided results stating that the machine removed $80 \%$ of the secretions produced.

\section{RESULT ANALYSIS}

\begin{tabular}{|c|c|c|c|c|c|c|c|}
\hline $\begin{array}{l}\text { Paper } \\
\text { Title }\end{array}$ & $\begin{array}{c}\text { Types } \\
\text { of } \\
\text { Patients }\end{array}$ & $\begin{array}{c}\text { Cost } \\
\text { Effective } \\
\text { and Portability }\end{array}$ & $\begin{array}{c}\text { Safety } \\
\text { Measures }\end{array}$ & $\begin{array}{l}\text { Ventilation } \\
\text { Technique }\end{array}$ & $\begin{array}{c}\text { Mechanism } \\
\text { Used }\end{array}$ & $\begin{array}{l}\text { Feedback } \\
\text { System }\end{array}$ & Analysis \\
\hline $\begin{array}{l}\text { Design, } \\
\text { Modelling, } \\
\text { Prototyping } \\
\text { and Closed } \\
\text { Loop } \\
\text { Control of a } \\
\text { Mechanical } \\
\text { Ventilator } \\
\text { for Newborn } \\
\text { Babies }\end{array}$ & $\begin{array}{c}\text { Only } \\
\text { applicable } \\
\text { for Neonates } \\
\text { or New } \\
\text { born } \\
\text { babies. }\end{array}$ & $\begin{array}{l}\text { Portability } \\
\text { is easy as } \\
\text { the packaging } \\
\text { is compact } \\
\text { but it is } \\
\text { not cost } \\
\text { effective. }\end{array}$ & $\begin{array}{l}\text { This does } \\
\text { not have } \\
\text { any } \\
\text { emergency } \\
\text { stop } \\
\text { button. }\end{array}$ & $\begin{array}{c}\text { It uses } \\
\text { Positive } \\
\text { Airway } \\
\text { Pressure. }\end{array}$ & $\begin{array}{l}\text { It uses } \\
\text { an oxygen } \\
\text { cylinder } \\
\text { for } \\
\text { respiration. }\end{array}$ & $\begin{array}{l}\text { Closed } \\
\text { Loop } \\
\text { control } \\
\text { system } \\
\text { is used } \\
\text { with the } \\
\text { help of } \\
\text { sensors. }\end{array}$ & $\begin{array}{l}\text { The } \\
\text { microcon } \\
\text { troller, } \\
\text { LPC1768, is } \\
\text { more complex, } \\
\text { has fewer } \\
\text { libraries and } \\
\text { is costly. } \\
\text { Whereas, } \\
\text { Arduino DUE, } \\
\text { is cheaper, } \\
\text { easy to use } \\
\text { and has } \\
\text { the same }\end{array}$ \\
\hline $\begin{array}{l}\text { Designing an } \\
\text { Electro- } \\
\text { Mechanical } \\
\text { Ventilator } \\
\text { Based on } \\
\text { Double CAM } \\
\text { Integration } \\
\text { Mechanism }\end{array}$ & $\begin{array}{c}\text { It is } \\
\text { applicable } \\
\text { for all } \\
\text { types of } \\
\text { patients, i.e. } \\
\text { Adult, } \\
\text { pediatric } \\
\text { and neonate }\end{array}$ & $\begin{array}{l}\text { It is cost } \\
\text { effective } \\
\text { as well as } \\
\text { compact } \\
\text { so that } \\
\text { it can be } \\
\text { used } \\
\text { anywhere }\end{array}$ & $\begin{array}{l}\text { To prevent } \\
\text { Bacteria } \\
\text { and germ } \\
\text { attack a filter } \\
\text { is used at } \\
\text { the inlet of } \\
\text { the bag, } \\
\text { which could } \\
\text { be changed } \\
\text { regularly. }\end{array}$ & $\begin{array}{c}\text { It uses } \\
\text { Positive } \\
\text { Airway } \\
\text { Pressure } \\
\text { ventilation. }\end{array}$ & $\begin{array}{c}\text { Used a } \\
\text { bag-valve } \\
\text {-mask } \\
\text { ventilation } \\
\text { mechanism. }\end{array}$ & $\begin{array}{l}\text { There is } \\
\text { no } \\
\text { provision } \\
\text { for any } \\
\text { feedback } \\
\text { system. }\end{array}$ & $\begin{array}{l}\text { architecture. } \\
\text { Although } \\
\text { these } \\
\text { ventilators } \\
\text { maintain } \\
\text { respiration } \\
\text { functionality, } \\
\text { this is often } \\
\text { accompanied } \\
\text { by organ } \\
\text { damage due } \\
\text { to the large } \\
\text { volume of } \\
\text { the air } \\
\text { injection }\end{array}$ \\
\hline
\end{tabular}


Continue Table 1

\begin{tabular}{|c|c|c|c|c|c|c|c|}
\hline $\begin{array}{l}\text { Design } \\
\text { and Study } \\
\text { of a Portable } \\
\text { High- } \\
\text { frequency } \\
\text { Ventilator } \\
\text { for Clinical } \\
\text { Applications }\end{array}$ & $\begin{array}{c}\text { This } \\
\text { ventilator } \\
\text { is applicable } \\
\text { for all types } \\
\text { of patients, } \\
\text { i.e. Adult, } \\
\text { pediatric } \\
\text { and neonate }\end{array}$ & $\begin{array}{l}\text { It is } \\
\text { portable } \\
\text { but not } \\
\text { cost } \\
\text { effective. }\end{array}$ & $\begin{array}{l}\text { It injects } \\
\text { Smaller } \\
\text { tidal volume } \\
\text { which reduces } \\
\text { the chances } \\
\text { of chronic } \\
\text { lung injury } \\
\text { in the long- } \\
\text { term treatment }\end{array}$ & $\begin{array}{c}\text { The } \\
\text { ventilator } \\
\text { uses } \\
\text { High } \\
\text { Frequency } \\
\text { Jet } \\
\text { Ventilation }\end{array}$ & $\begin{array}{c}\text { A } \\
\text { switchable } \\
\text { capacitor } \\
\text { array } \\
\text { was } \\
\text { used } \\
\text { to reach } \\
\text { a constant } \\
\text { injection } \\
\text { frequency. }\end{array}$ & \begin{tabular}{|c|} 
A pressure \\
feedback \\
technique \\
is \\
implemented \\
to adjust the \\
air flow \\
and I:E \\
ratio for \\
the \\
required \\
levels.
\end{tabular} & $\begin{array}{l}\text { To make } \\
\text { it a perfect } \\
\text { ventilator } \\
\text { device } \\
\text { like VAP } \\
\text { care could } \\
\text { be used } \\
\text { along with } \\
\text { it, to prevent } \\
\text { nosocomial } \\
\text { infections. }\end{array}$ \\
\hline $\begin{array}{l}\text { Technical } \\
\text { Evaluation } \\
\text { of an AI } \\
\text { based } \\
\text { Secretion } \\
\text { and Oral } \\
\text { Hygiene } \\
\text { Management } \\
\text { System for } \\
\text { Ventilator- } \\
\text { associated } \\
\text { Pneumonia }\end{array}$ & $\begin{array}{l}\text { Applicable for } \\
\text { all types } \\
\text { of patients, } \\
\text { i.e. Adult, } \\
\text { pediatric } \\
\text { and neonate }\end{array}$ & $\begin{array}{l}\text { Portable } \\
\text { and cost } \\
\text { effective }\end{array}$ & $\begin{array}{c}\text { It is a device } \\
\text { which prevents } \\
\text { any nosocomial } \\
\text { infection during } \\
\text { endotracheal } \\
\text { intubation. }\end{array}$ & None & None & $\begin{array}{c}\text { Since it } \\
\text { is AI driven, } \\
\text { on detection } \\
\text { of any } \\
\text { infection } \\
\text { lavage is } \\
\text { sprayed. }\end{array}$ & $\begin{array}{l}\text { It can be } \\
\text { used along } \\
\text { with } \\
\text { ventilators } \\
\text { to prevent } \\
\text { infections. }\end{array}$ \\
\hline $\begin{array}{l}\text { Prototyping of } \\
\text { Artificial } \\
\text { Respiration } \\
\text { Machine } \\
\text { Using } \\
\text { AMBU Bag } \\
\text { Compression }\end{array}$ & $\begin{array}{l}\text { Can be used } \\
\text { for all } \\
\text { categories of } \\
\text { patients. }\end{array}$ & $\begin{array}{l}\text { Low cost } \\
\text { ventilator. } \\
\text { This } \\
\text { ventilator } \\
\text { system is } \\
\text { compact, } \\
\text { so portable }\end{array}$ & $\begin{array}{l}\text { It beeps } \\
\text { when there } \\
\text { is a pressure } \\
\text { change or } \\
\text { gives trigger } \\
\text { alert at } \\
\text { regular } \\
\text { intervals of } \\
\text { time for } \\
\text { respirations } \\
\text { pattern }\end{array}$ & $\begin{array}{c}\text { It uses } \\
\text { Positive } \\
\text { Airway } \\
\text { Pressure } \\
\text { ventilation }\end{array}$ & $\begin{array}{c}\text { Used two } \\
\text { different } \\
\text { mechanisms } \\
\text { for } \\
\text { compression } \\
\text { of AMBU } \\
\text { bag: Chained } \\
\text { Plank and } \\
\text { Camshaft } \\
\text { Mechanism }\end{array}$ & $\begin{array}{c}\text { No } \\
\text { feedback } \\
\text { system } \\
\text { was } \\
\text { used. }\end{array}$ & $\begin{array}{c}\text { Instead } \\
\text { of a } \\
\text { thermistor } \\
\text { and CO2 } \\
\text { sensor, flow } \\
\text { rate sensor } \\
\text { and pressure } \\
\text { sensor could } \\
\text { be used } \\
\text { for breath } \\
\text { sensing } \\
\text { purposes. }\end{array}$ \\
\hline $\begin{array}{l}\text { Portable, } \\
\text { Low Cost, } \\
\text { Closed-Loop } \\
\text { Mechanical } \\
\text { Ventilation } \\
\text { Using Feedback } \\
\text { from Optically } \\
\text { Isolated } \\
\text { Analog }\end{array}$ & $\begin{array}{c}\text { For all } \\
\text { categories } \\
\text { of patients }\end{array}$ & $\begin{array}{l}\text { This prototype } \\
\text { is a low } \\
\text { Sensors cost } \\
\text { and portable } \\
\text { ventilator }\end{array}$ & $\begin{array}{c}\text { This device } \\
\text { does not } \\
\text { have any } \\
\text { emergency } \\
\text { button } \\
\text { or a bacteria } \\
\text { filter for } \\
\text { its safety. }\end{array}$ & $\begin{array}{c}\text { It uses } \\
\text { Positive } \\
\text { Airway } \\
\text { Pressure } \\
\text { ventilation }\end{array}$ & $\begin{array}{c}\text { A DC air } \\
\text { pump along } \\
\text { with a buck } \\
\text { converter is } \\
\text { used to } \\
\text { supply air } \\
\text { for } \\
\text { respiration. }\end{array}$ & $\begin{array}{c}\text { Feedback is } \\
\text { generated } \\
\text { from } \\
\text { Optically } \\
\text { Isolated } \\
\text { Analog } \\
\text { Sensors }\end{array}$ & $\begin{array}{c}\text { A LCD } \\
\text { screen and } \\
\text { buttons could } \\
\text { be used instead } \\
\text { of a Raspberry } \\
\text { Pi to make } \\
\text { things simple. }\end{array}$ \\
\hline DEVEN & $\begin{array}{l}\text { Applicable } \\
\text { for all types } \\
\text { of patients, } \\
\text { i.e. Adult, } \\
\text { pediatric } \\
\text { and neonate }\end{array}$ & $\begin{array}{c}\text { Portable } \\
\text { and Low } \\
\text { Cost }\end{array}$ & $\begin{array}{c}\text { It has high } \\
\text { - and low- } \\
\text { level alarms } \\
\text { for inspiration } \\
\text { pressure, } \\
\text { tidal volume, } \\
\mathrm{BPM} \text { I:E ratio, } \\
\mathrm{FiO}_{2} \text { and PEEP. }\end{array}$ & $\begin{array}{l}\text { The } \\
\text { ventilator } \\
\text { uses High } \\
\text { Frequency } \\
\text { Jet } \\
\text { Ventilation }\end{array}$ & $\begin{array}{c}\text { Compressed } \\
\text { air } \\
\text { from } \\
\text { compressor } \\
\text { and air } \\
\text { reservoir is } \\
\text { used and } \\
\text { oxygen is }\end{array}$ & $\begin{array}{l}\text { Solenoid } \\
\text { valve } \\
\text { to control } \\
\text { Breathing } \\
\text { rate } \\
\text { and I:E } \\
\text { ratio is } \\
\text { used. Also, }\end{array}$ & $\begin{array}{l}\text { Filters can } \\
\text { be used } \\
\text { in Inspiratory } \\
\text { and Expiratory } \\
\text { limbs and } \\
\text { near the } \\
\text { patient inlet. }\end{array}$ \\
\hline
\end{tabular}




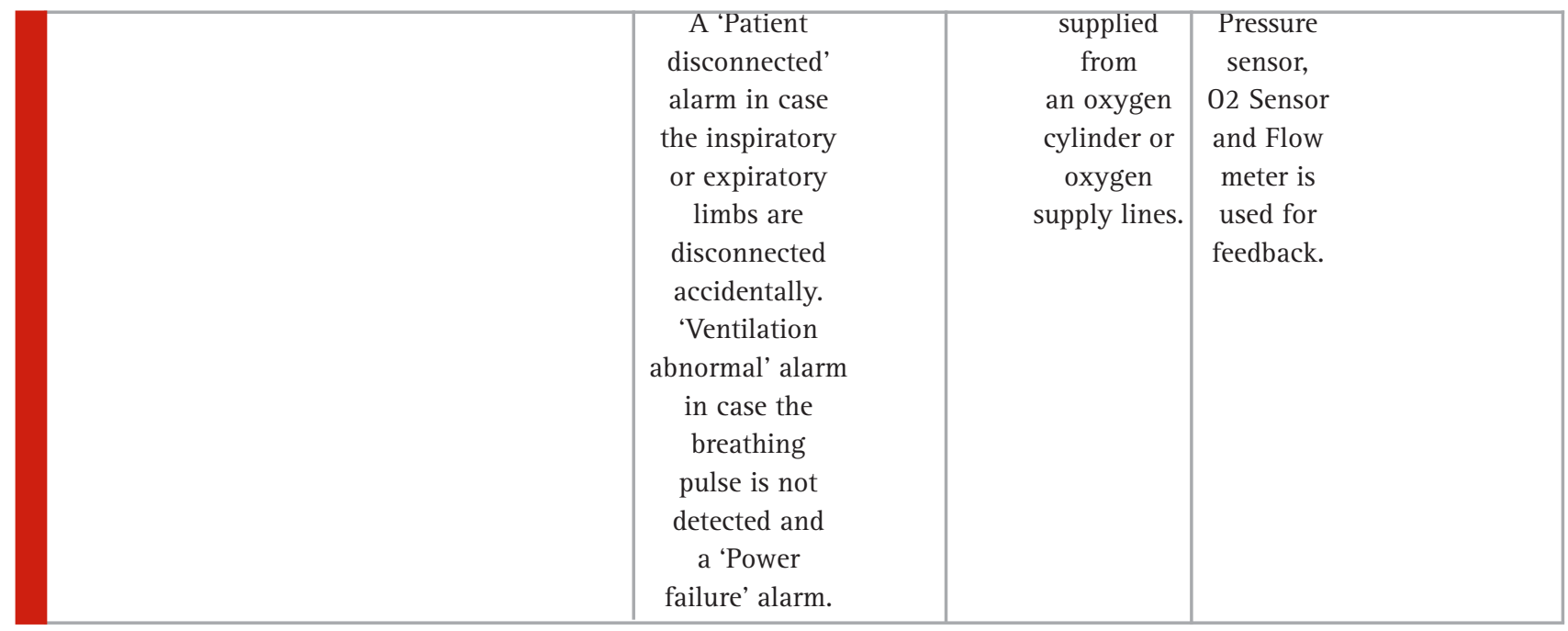

\section{PROPOSED METHODOLOGY}

Figure 1: Proposed Block Diagram

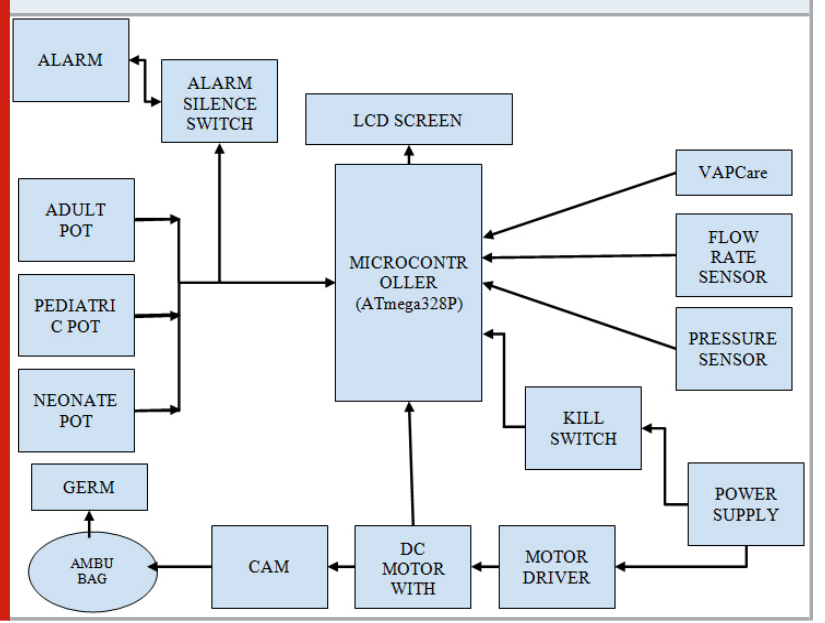

We are proposing that we should use Positive Pressure Airway compressions of AMBU Bag with the given components because these components are readily available and low in cost compared to the ventilators of the other researchers. The Arms of the CAM can be made up of acrylic sheets and laser cutting instead of 3D printing as 3D printing is costlier, provided the laser cutting and acrylic sheet gives the same precision and strength.

Fig. 1 shows that we have interfaced microcontroller Atmega328P with LCD screen for display of control signals and different mode. A pressure sensor(NXP MPX2200DP) is interfaced for measurement of pressure so prevent barotrauma. Key ventilation specification for the maximum Airway pressure should be around $40 \mathrm{~cm}$ H2O. So, if pressure exceeds an alarm is interfaced so that it can alert the attending. And to switch it off, a switch is also given. Which when noticed should be manually put off.

The flow rate sensor (NXP MPX2200DP) is interfaced to measure tidal volume. For both flower Rate sensor and
Pressure sensor we can use the same type of sensor (NXP MPX2200DP). A VAPCare is used to prevent nosocomial infection caused due to endotracheal intubation. For power supply we are using SMPS and a Battery backup system can also be implemented. A motor driver is used to drive the motor and the motor will control the arms, so that it compresses and decompresses the AMBU Bag. A germ attack filter is used to filter out the germ that can contaminate the inlet of the AMBU bag harming the patient's organ. Here we have used three modes which will be used for different settings according to the patient's age and criteria. For precession of respiratory rates a encoder attached with the motor is used so that the compressions and decompression can be monitored. And the CAM arm can make moments in particular angles. We also have provided a KILL Switch so that at emergencies the attending nearby can close the system immediately.

\section{CONCLUSION}

The ventilators mentioned by all researchers were effective and proved their capability while testing them. The AMBU bag technique could be used for emergency cases only, like in the ambulance but not for continuous ventilation purposes. The point that it can't constantly maintain the I:E ratio can cause barotrauma. With some new techniques in future it is possible to eradicate this problem. On the other hand, high frequency jet ventilators are durable and inexpensive with very little error margin. Devices like VAPcare can be used with mechanical-ventilators to prevent bacterial infection during ventilation. With current research in this field due to the COVID-19 pandemic, it is expected that an errorless ventilation mechanism will soon come.

\section{ACKNOWLEDGEMENTS}

This paper and the research behind it would not have been possible without the exceptional support of our guide Dr. Milind Vyavhare, who is an Associate Professor at Government Medical College, Nagpur. We would like to express our deep gratitude towards him, for his patient 
Bhole et al.,

guidance, enthusiastic encouragement, useful critiques and assistance in keeping our progress on schedule throughout the work. His enthusiasm and constant motivation helped us a lot and kept our work on track.

\section{REFERENCES}

Aït-Khaled N, Enarson D, Bousquet J (2001) Chronic respiratory diseases in developing countries: the burden and strategies for prevention and management, Bulletin of the World Health Organization, 79 (10)[249citations]. Source

A. S. Tauheed et al., "Technical Evaluation of an AI based Secretion and Oral Hygiene Management System for Ventilator-associated Pneumonia," 2019 11th International Conference on Communication Systems \&t Networks (COMSNETS), Bengaluru, India, 2019, pp. 838841, doi: 10.1109/COMSNETS.2019.8711169. Source F. S. SAYIN and H. ERDAL, "Design, Modelling, Prototyping and Closed Loop Control of a Mechanical Ventilator for Newborn Babies," 2018 6th International Conference on Control Engineering \& Information Technology (CEIT), Istanbul, Turkey, 2018, pp. 1-5, doi: 10.1109/CEIT.2018.8751846. Source

Johar, H.S., Yadav, K. DRD0's Portable Low-Cost Ventilator: "DEVEN". Trans Indian Natl. Acad. Eng. 5, 365-371 (2020). Source

L. Mertz, "Quick Thinking Turns out Low-Cost Ventilators," in IEEE Pulse, vol. 11, no. 3, pp. 31-34, May-June 2020, doi: 10.1109/MPULS.2020.2995436. Source

Miller J: Germany, Italy rush to buy life-saving ventilators as manufacturers warn of shortages. Source

M. R. Islam, M. Ahmad, M. S. Hossain, M. Muinul Islam and S. F. Uddin Ahmed, "Designing an ElectroMechanical Ventilator Based on Double CAM Integration Mechanism," 2019 1st International Conference on Advances in Science, Engineering and Robotics Technology (ICASERT), Dhaka, Bangladesh, 2019, pp. 1-6, doi: 10.1109/ICASERT.2019.8934562. Source M. Shahid, "Prototyping of Artificial Respiration Machine Using AMBU Bag Compression," 2019 International Conference on Electronics, Information, and Communication (ICEIC), Auckland, New Zealand, 2019, pp. 1-6, doi: 10.23919/ELINFOCOM.2019.8706360. Source

Ramsey L: Hospitals could be overwhelmed with patients and run out of beds and ventilators as the coronavirus pushes the US healthcare system to its limits. Business Insider. 2020.Source

S. Lu et al., "Design and Study of a Portable Highfrequency Ventilator for Clinical Applications," 2019 41st Annual International Conference of the IEEE Engineering in Medicine and Biology Society (EMBC), Berlin, Germany, 2019, pp. 2353-2356, doi: 10.1109/ EMBC.2019.8857805. Source

S. Zulfiqar, H. Nadeem, Z. Tahir, M. Mazhar and K. M. Hasan, "Portable, Low Cost, Closed-Loop Mechanical Ventilation Using Feedback from Optically Isolated Analog Sensors," TENCON 2018 - 2018 IEEE Region 10 Conference, Jeju, Korea (South), 2018, pp. 1913-1916, doi: 10.1109/TENCON.2018.8650277. Source 